\title{
Rethinking Racial Threat: A Comparison \\ of Latino Population Change in the North and South
}

\author{
Patrick R. Miller
}

he racial dynamics of Southern politics have long been defined by the divide between whites and blacks, but recent years have seen high levels of Latino growth throughout the region. This work examines the effect that the influx of Latinos has had on attitudes toward immigration in the United States, and explores how racial threat resulting from Latino growth manifests itself differently in the North versus the South. Results suggest that traditional ways of conceptualizing racial threat may be inappropriate to capture the unique dynamics of Latino growth, especially in the South, and different measures of threat are proposed and tested. Data come from the 2000 National Election Survey (NES) merged with data from the U.S. Census.

Globalization is changing the United States in myriad ways, but its effects are perhaps the most apparent in the South. Long a bastion of traditionalism in all its forms, the region is undergoing economic and social transformations that just a few decades ago would have been almost unimaginable. Once so poor and dependent upon agriculture that Franklin D. Roosevelt labeled it "the nation's number one economic problem," the South is now home to a vibrant middle class and many of the world's largest corporations. However, porous global borders have drained the South of hundreds of thousands of manufacturing jobs, especially as textile mills abandon it for cheap labor abroad.

Globalization, however, has also altered the racial dynamics of the region. The politics of race in the South has long been defined by the dichotomy between whites and African Americans, but the past twenty years have seen an explosion of Latinos ${ }^{1}$ in the region (Goerman 2006; Mantero 2008; Mohl 2005). Though Mexicans have been present in Texas since its 1845 annexation and Cubans have inhabited Florida in large numbers since the early 1960s, Hispanics are a new population in most of the South (McClain et al. 2006). As V.O. Key observed in 1949, the politics of the South is the politics of race. Even today, race pervades almost every aspect of political conflict in the region. For the first time in most of the South, however, Hispanics are a part of that dialogue.

The introduction of a rapidly growing immigrant group may upset the delicate racial balance that has evolved in the South in ways that political scientists are only beginning to grasp. McClain and her colleagues

PATRICK R. MILLER is a post doctoral survey research associate at the Duke Initiative on Survey Methodology at Duke University.

The American Review of Politics, Vol. 31, Fall, 2010: 203-221

(c)2010 The American Review of Politics 
(McClain 1993, 2006; McClain and Karnig 1990; McClain et al. 2006; Meier et al. 2004) have documented the often contentious relationship between blacks and Latinos, especially in the South, over access to limited resources and status. Indeed, Hispanic growth in the region is particularly controversial due to the ongoing illegal immigration debate. The Pew Hispanic Center (Passel and Cohn 2009) estimates that 76 percent of illegal immigrants in the U.S. in 2008 were Latino, a figure that is likely higher in the South given the lower levels of non-Latino immigration there. Pew estimates that up to 65 percent of Latinos in some Southern states are illegal. As nearly 60 percent of Latinos in the South are foreign-born (Pew 2005), their rapid growth and the immigration debate may be inextricably linked in the South in ways that they may not be in areas with more established Hispanic populations.

This article explores the relationship between Latino population growth and immigration attitudes, focusing especially on the role of racial threat in shaping policy preferences. By combining information about the racial contexts in which survey respondents live with their responses to questions about immigration policy in the 2000 NES, this research suggests that racial threat is a significant negative influence on immigration attitudes. However, those threat dynamics appear in ways that political scientists traditionally do not examine. I also demonstrate that threat may be more salient in the South as compared to the North. Overall, this research suggests that the growth of Latinos, especially in the South, affects attitudes in subtle ways that may contribute to a more divisive racial environment as the nation continues to diversify.

\section{Latinos and Immigration in the South}

The rise in Latino population which the South has experienced in the last two decades has, indeed, been a national phenomenon. Between 1990 and 2000, the Hispanic population nationwide grew by 61.2 percent to 35.3 million (Mohl 2005), surging Latinos past African Americans to become the nation's largest minority group in 2003. The 2008 American Community Survey (ACS) estimate puts the Hispanic population at a rapidly growing 15.4 percent of the population, whereas blacks have remained at a fairly stable 12 percent for most of the last twenty years. Given current population trends, whites should lose their national majority status in the 2040s (Passel and Cohn 2008).

The largest percentage increases in Latino population in the 2000 Census came in the South. The roughly 60 percent national increase in Hispanics during the 1990s was overshadowed by triple digit gains in most Southern states. Growth rates ranged from a low of 15.8 percent in Louisiana to a high 
of 393.8 percent in North Carolina, the state with the fastest growing Hispanic population nationwide (Mohl 2005). Only Louisiana, Texas (53.7\%), and Florida $(70.4 \%)$ failed to double their Latino populations over the decade. Many metro areas saw growth rates that outpaced the phenomenal increases region-wide. The Fayetteville, Arkansas metro experienced 1,630.1 percent growth in its Latino population, with North Carolina's Triad and Triangle ranking second and third at 776.7 percent and 704.7 percent respectively. This growth was fueled by border enforcement policies that shifted illegal immigration routes from the Southwest to the Southeast, aggressive recruitment of workers by the agricultural sector, chain migration, and higher birth rates among new immigrants in the region as compared to the lower birth rates of more established Latino populations elsewhere (Goerman 2006 offers more thorough discussion).

The Southern Latino population grew at a larger rate than the African American or white populations in the region during the 1990s, which increased by 21 percent and 11 percent respectively (Pew Hispanic Center 2005). However, the black populations of nine of the eleven Southern states grew by more numerically during this period than did Hispanics. Only in North Carolina and Arkansas did raw Latino growth outstrip black growth. Still, that Hispanics would numerically outstrip African Americans anywhere during a period of substantial black migration to the South from the North is remarkable. Though Latinos have become the largest minority in some Southern counties that historically lacked Hispanic populations, blacks are still the largest minority group in the vast majority of counties in the region and in every Southern state but Florida and Texas.

Though Latinos have substantially increased their share of the Southern population, their remarkable growth rates are mostly attributed to the fact that Hispanics were a very small proportion of the population in the 1990 Census (Pew Hispanic Center 2005). North Carolina, for example, may have had the fastest growing Latino population by increasing its count from 76,726 in 1990 to 378,963 , but the sheer size of that growth $(302,237$ individuals) lagged behind the actual numerical growth in traditional Latino destination states such as California (3.3 million increase, but only a $43 \%$ growth rate), New York $(650,000 ; 30 \%)$, Illinois $(626,000 ; 69 \%)$, and New Jersey $(377,000 ; 51 \%)$.

Though the incredible Latino growth rates in the South in the 1990s stem from their small population base, their presence is still a remarkable demographic evolution as many Southerners can recall recent times when Hispanics were virtually nonexistent in their communities. Indeed, Latinos have continued to expand in the South since 2000. In North Carolina, the state with the largest Latino increase in the 1990s, the 2008 ACS estimated that Latinos were 7.4 percent of the population, up from 4.7 percent in 2000 , 
and have grown by 80.2 percent to nearly 700,000 . Northern Virginia and Atlanta have become new Latino destinations with metropolitan growth rates among the highest nationally.

\section{Racial Attitudes and Attitudes toward Immigrants}

As discussed above, there is substantial overlap between immigrant and Latino groups in the South. Given regional immigration statistics and the common association of "immigrant" and "Hispanic" in the minds of many Americans (Garcia and Sanchez 2008), there is likely a connection between perceptions of Latinos and immigration attitudes. This connection may be especially strong in the South given its higher proportion of Latino immigrants as compared to the North (Reimers 2005) and the rapid growth of Latinos as a new population in most of the region. Outside of a few urban areas, there are few non-Latino foreign immigrants entering the South (Reimers 2005), so the immigrants in the communities of average Southerners are overwhelmingly Hispanic.

If there is a psychological association of Latinos and immigrants, many of the concepts used to study racial dynamics may predict immigration attitudes, especially racial threat. Threat is traditionally conceptualized in the aggregate when referring to proximity of groups, but at the individual level to measure personal interaction with out-group members (Stein et al. 2000). I only use aggregate measures of threat, largely because individual contact measures are not available in most public data sets.

Aggregate threat is often operationalized as the size of a minority group in a defined geographic space, a tradition dating to Key (1949) and his finding that whites living in the Southern counties with the highest concentrations of blacks were the strongest supporters of segregationist candidates. His finding that proximity, meaning that two groups are geographically close to each other, yields racial hostility has been replicated many times in the context of white attitudes towards blacks (Black 1976; Fossett and Kiecolt 1989; Giles 1977; Giles and Evans 1985; Giles and Hertz 1994; Glaser 1994; Matthews and Prothro 1966; Taylor 1998; Wright 1977). This proximity effect has also replicated to non-Southern settings, mostly major metropolitan areas in the Northeast and Midwest (Huckfeldt and Kohlfield 1989). Similar proximity effects have been less consistently observed with white attitudes towards Latinos and Asians (Citrin et al. 1990; Frendreis and Tatalovich 1997; Hood and Morris 1997).

Key and other scholars posit three types of threat from proximity to a minority: political, economic, and status. Political threat implies that a minority may take control of political goods such as elected offices or government appointments either through their own voting power or by garnering 
votes from sympathizers. Economic threat refers to the ability of a minority to redirect economic resources to itself or to reduce the wealth of the majority (Rieder 1985). Status threat means competition for influence in institutions, professions, or society (Oliver and Mendelberg 2000). Kinder and Mendelberg (1995) argue that when whites are faced with a threat from a minority, in-group social identities activate that make whites more negative towards minority out-groups. They argue that proximity primes racial stereotypes that elicit prejudiced behavior and that these stereotypes are difficult to combat as they are so engrained in out-group schemata.

Some scholars have argued that threat is more contextual than a simple "minority elicits threat" story and have proposed specific conditions under which proximity feeds white negativity toward minorities (Alport 1954; Amir 1969, Ellison and Powers 1994; Jackman and Crane 1986; Pettigrew 1971; Powers and Ellison 1995; Sigelman and Welch 1993; Stephan and Stephan 1985; Welch et al. 2001). If a minority is labeled inferior in a way relevant to a group interaction, this stigma can reinforce minority stereotypes. Likewise, group competition over scare resources can reinforce negative out-group evaluations. At the individual level, the arena of contact between group members fundamentally matters. Dynamics among neighbors, for example, are different than when majority and minority group members interact in settings that are less threatening to majority privilege. Group interdependence is also relevant as groups which can prosper independently of one another have less incentive to maintain positive relations.

Proximity and the context of group interaction, then, are key in shaping majority views of minorities. When proximity is examined in the aggregate, it tends to make individual racial attitudes more negative. Though most of this literature applies to white attitudes toward blacks, there is no theoretical reason to believe that aggregate threat will not affect the attitudes of whites or blacks toward Latinos. Thus, aggregate measures of Latino population may affect attitudes toward policies associated with Hispanics, namely immigration. As the threat literature tends to find stronger effects in the South given the region's historical preoccupation with race, Latino threat may be most evident among Southerners. Indeed, the novelty of Hispanics in most of the South, and their high growth rates may magnify threat given the unique demographic profile of the region.

\section{Hypotheses}

I expect to observe a relationship between proximity to Latinos and immigration attitudes. Specifically, I propose that aggregate proximity to Latinos makes immigration attitudes more negative, meaning more "antiimmigrant." The tradition begun with Key (1949) has been to operationalize 
racial context as the percentage of a minority group that inhabits a defined geographical space. Most of the studies discussed earlier use the percentage of a county or neighborhood population that belongs to a specific minority group as a proxy for the level of threat which that minority induces against the majority. The higher the minority population, the greater the threat. I measure Latino population at the county level to make the results more comparable to previous work. ${ }^{2}$ Thus, I posit:

As the percentage of a county's population that is Latino grows, immigration attitudes of individuals in the county will become more negative.

Despite their growth, Latinos still comprise a relatively small proportion of the population in most of the South. While the sheer percentage of Hispanics in the region is not trivial, it is the percentage growth in Hispanic population that has been most dramatic in recent decades with triple digit growth rates in most Southern states. Non-Hispanics, then, may perceive Latinos as a threat not because they comprise a large percentage of the local population, but because they are growing so rapidly.

As the Latino growth rate of a county increases, immigration attitudes of individuals in the county will become more negative.

Given conflicts between African Americans and Latinos, blacks may be more sensitive to Hispanic population increases. Thus, all things being equal, black immigration attitudes may respond more negatively than white attitudes in response to the same population change. As the largest minority in most of the region, blacks may also be more aware of their relative balance with Hispanics in a community.

African Americans will be more responsive to county level changes in Latino population than whites.

As the ratio of blacks to Hispanics in a county decreases, the immigration attitudes of blacks in that county will become more negative. Whites, however, will be unresponsive to this change.

\section{Data}

The 2000 NES is the main source of data. ${ }^{3}$ As a nationally representative sample, the NES allows reliable comparisons between respondents in the South (defined as the 11 states of the Confederacy) and the North 
(defined as the other 37 contiguous states sampled in the NES). The published version of the NES does not include geographic locators below the state level, but the confidential file containing this information from the NES was merged with the public dataset. ${ }^{4}$ County demographic data for 1990 and 2000 from the Census were incorporated into the NES data.

\section{Measures}

Dependent Variables. The 2000 NES included two immigration policy items: immigration level and border security funding. For immigration level, respondents were asked, "Do you think the number of immigrants from foreign countries who are permitted to come to the United States to live should be increased, decreased, or left the same as it is now? A little or a lot?" Responses lie on a 5-point scale $(1=$ decrease a lot, 5 = increase a lot; $M=2.836 ; S D=1.090)$. For bordering funding, respondents were asked, "What about tightening border security to prevent illegal immigration? Should federal spending on tightening border security to prevent illegal immigration be increased, decreased, or kept about the same?" Responses are on a 3 -point scale $(1=$ decreased, $2=$ kept about the same, 3 = increased; $M=2.425 ; S D=.674)$.

Latino Population. The Census website was used to obtain racial demographics for all counties where NES respondents lived, including the Hispanic percentage of a county's population. ${ }^{5}$ The average county in the sample had a 7.7 percent Latino population in $2000(S D=11.2 \%, \operatorname{Min}=$ $.4 \%, \operatorname{Max}=88.3 \%, N=525$ ). The average Southern county had a Hispanic population of 8.5 percent in 2000 as compared to 7.3 percent for the North, but that mean falls to 2.9 percent when Texas and Florida are excluded from the Southern average. Thus, in Southern states that were new destinations for Latino immigrants in the 1990s, Hispanics were still a small proportion of county populations despite their growth rates.

Latino Population Change. Using 1990 as a baseline, I calculated the percentage change in Hispanic population through 2000. If county X, for example, doubled from 200 to 400 Latinos during this period, its score would be 100 percent. The mean county increase in the sample was 250.5 percent $(S D=183.9 \%, \operatorname{Min}=11.4 \%, \operatorname{Max}=1779.4 \%)$. The Southern mean, including Texas and Florida, was 311.7 percent as compared to 217.4 percent in the North $[t(523)=-5.773, p<.001]$, but it jumps to 382 percent excluding those two states. Northern counties in the sample with higher than average growth rates were more likely to have already had larger Latino populations in 1990, whereas the highest growth counties in the South did not. Thus, Hispanics in the North were more likely to grow in areas where Latinos were already present, whereas growth in the South was more likely 
to indicate new Latino populations settling. Thus, the context of Latino growth differs by region.

Black-Latino Ratio Change. The change in the ratio of blacks to Latinos in each county from 1990 to 2000 was calculated as [-100 X (1 (2000 ratio)/(1990 ratio))]. If county Y had 900 blacks and 100 Hispanics in 1990 , that ratio is $9: 1$. If the ratio changed by 2000 to $3: 1$, then the blackLatino ratio was cut by $2 / 3$. The ratio change for county $\mathrm{Y}$ would be -66.7 percent, or $[-100 \mathrm{X}(1-(3) /(9))]$. The mean change in the sample was -25.5 percent, so the average change in the ratio of blacks to Hispanics over the 1990 s was a decrease of roughly a quarter. Southern counties had an average change of -41.8 percent, but the Northern average was -16.6 percent $[t(523)$ $=4.789, p<.001]$. The Southern mean increases to -49.1 percent without Texas and Florida. Thus, in new Latino growth states in the South, the ratio of blacks to Hispanics was cut on average in half in the sampled counties over the decade as compared to roughly a 20 percent decrease in the North. Indeed, the median change in the South was -58.6 percent as compared to 27.8 percent in the North, underscoring the dramatic change in the balance of minority populations in the region.

Controls. Political controls were used for factors that may affect immigration attitudes, including partisanship (7-pt., $1=$ strong Democrat, $7=$ strong Republican), ideology (7-pt., $1=$ strong liberal, $7=$ strong conservative), and prospective economic expectations (5-pt., 1 = economy will get much worse in the next year, 5 = get much better; Citrin et al. 1997; Kinder 2003; Scheve and Slaughter 2001). I also use the NES authoritarianism scale $(\alpha=.601$, scaled \pm 4 , higher values show greater authoritarianism; Hetherington and Weiler 2009) and two ethnocentrism (Kinder and Kam 2009; including out-group affect calculated as the feeling thermometer score of a respondent's racial in-group minus the mean rating of all racial out-groups and out-group stereotyping calculated as the mean stereotype rating of a respondent's racial in-group minus the average out-group score on that trait; higher values indicate greater ethnocentrism).

Also included as controls are age, education (7-pt.), income (22-pt.), and dummies for sex $(1=$ female $)$ and region $(1=$ South $)$. As I am only interested in racial threat effects on the attitudes of blacks and whites, I constrict the analysis to those two races and indicate race with a dummy variable $(1=$ black $)$. Missing predictor values are imputed with AmeliaView, but missing dependent variable values are left missing.

\section{Threat Effects on Immigration Attitudes}

Again, I propose three measures of county level racial threat that may affect immigration attitudes-Latino population percentage, percentage 
change in the Latino population from 1990 to 2000, and the change in the ratio of blacks to Latinos during the same period. In the analyses below, I estimate three models per dependent variable, each containing one of these aggregate measures interacted with dummies for region and/or race. All models are estimated with ordinal logistic regression and all interactions are the product of centered constituent terms. Only the fully specified models to test the hypotheses are presented due to space constraints.

Table 1 predicts the 5-point immigration level item. Three models are estimated, each with the same political and demographic controls. However, each model includes a different operationalization of racial threat and the appropriate interactions to test my hypotheses. The first column of estimates conceptualizes threat as the Latino percentage of a county population. This is the classic measure of threat from Key (1949), but adapted to Hispanics rather than blacks. The results give no support for the hypothesis that the percentage of Hispanics in the local population influences immigration attitudes. Percent Latino is insignificant both by itself and when interacted with the South dummy.

Especially in the South, Latinos are still a small share of most county populations despite their growth in the 1990s. Many respondents may perceive that Latinos in their communities are such a small part of the population that they do not constitute a collective threat. This may be especially true in counties with large recent influxes of Latinos who may not be fully integrated into local politics or connected to social services. Thus, the small size of most county level Hispanic populations and any disconnect between those Latinos and their communities may assuage perceptions of threat that might otherwise arise from the presence of a minority group.

The second results column replaces Latino percentage with Hispanic population growth from 1990 to 2000 . Again, this item represents the change in the county Latino population itself. ${ }^{6}$ Included in the model by itself, the Latino growth variable is not a significant predictor of immigration level preferences, but it is significant when interacted with the South dummy. Panel A in Figure 1 illustrates the combined predicted probability of selecting one of the two "decrease immigration" responses. The probabilities are plotted at the mean of Latino growth (251\%) and $\pm 1 S D(67 \%$ and $435 \%$ respectively).

The flat line in panel A shows that Latino growth has no significant effect on Northern immigration attitudes. Northern respondents in counties at $\pm 1 S D$ of Latino growth are equally likely to prefer decreasing immigration levels, but Southerners living in counties at +1 SD are 20.1 percent more likely to answer "decrease" than those in counties at -1 SD. Comparing the regions, Southerners in counties at the mean of Latino growth and above are significantly more likely to prefer decreasing immigration than Northerners. 
Table 1. Support for Increasing Immigration, 2000 NES

\begin{tabular}{|c|c|c|c|}
\hline & Latino $\%$ & Latino Growth & Ratio Change \\
\hline \multicolumn{4}{|l|}{ Political Attitudes } \\
\hline Authoritarianism & $.019(.023)$ & $.016(.023)$ & $.019(.022)$ \\
\hline Out-Group Affect & $-.018(.003)^{* * *}$ & $-.017(.003)^{* * *}$ & $-.017(.003) * * *$ \\
\hline Out-Group Traits & $.001(.017)$ & $.004(.017)$ & $.002(.017)$ \\
\hline Ideology & $-.138(.0340 * * *$ & $*-.133(.034)^{* * *}$ & $-.136(.035)^{* * *}$ \\
\hline Partisanship & $-.006(.028)$ & $-.009(.028)$ & $.003(.029)$ \\
\hline Economic Expectations & $.237(.069)^{* *}$ & $.207(.069)^{* *}$ & $.234(.069)^{* *}$ \\
\hline \multicolumn{4}{|l|}{ Demographics } \\
\hline Age & $.003(.003)$ & $.002(.003)$ & $.002(.003)$ \\
\hline Black & $.476(.298)+$ & $.348(.187)+$ & $.436(.429)$ \\
\hline Education & $.277(.035)^{* * *}$ & $.275(.034) * * *$ & $.271(.035)^{* * *}$ \\
\hline Female & $-.229(.092)^{*}$ & $-.221(.093)^{*}$ & $-.190(.091)^{*}$ \\
\hline Income & $.009(.015)$ & $.011(.015)$ & $.009(.015)$ \\
\hline South & $.141(.142)$ & $.154(.137)$ & $.057(.133)$ \\
\hline \multicolumn{4}{|c|}{ Threat Measures and Interactions } \\
\hline Latino $\%$ & $.465(.405)$ & & \\
\hline South X Latino \% & $-.897(.665)$ & & \\
\hline Latino Growth & & $-.001(.001)$ & \\
\hline South X Latino Growth & & $-.004(.001)^{* * *}$ & \\
\hline Ratio Change & & & $-.017(.016)$ \\
\hline Black X Ratio Change & & & $.004(.002)^{*}$ \\
\hline South X Ratio Change & & & $-.500(.612)$ \\
\hline Black X South & & & $-.002(.001)$ \\
\hline Black X South X Ratio Change & & & $-.006(.002)^{* *}$ \\
\hline$\tau_{1}$ & .751 & .806 & .738 \\
\hline$\tau_{2}$ & 1.499 & 1.555 & 1.487 \\
\hline$\tau_{3}$ & 4.171 & 4.226 & 4.161 \\
\hline$\tau_{4}$ & 5.183 & 5.240 & 5.173 \\
\hline LR & $163.94 * * *$ & $194.59 * * *$ & $163.63 * * *$ \\
\hline Pseudo- $\mathrm{R}^{2}$ & .068 & .062 & .064 \\
\hline $\mathrm{N}$ & 1528 & 1528 & 1528 \\
\hline
\end{tabular}

Thus, the growth in county Hispanic population itself exhibits a threat effect only on Southern respondents, especially those living in counties with higher growth rates. As discussed earlier, the context of Latino growth is fundamentally different between the regions. Race is traditionally more salient in the South and, unlike in the North, Southern counties with higher rates of Latino growth are more likely to be communities without established 
Figure 1. Predicted Probabilities of Decreased Immigration Response

\section{A. Latino Growth Interaction}

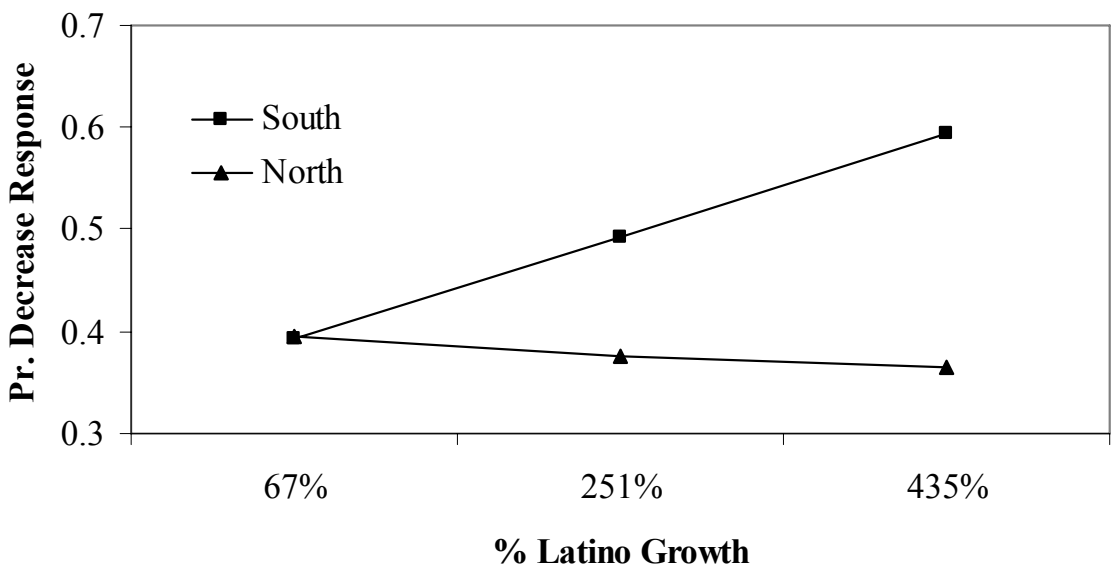

\section{B. Black-Latino Ratio Change Interactions}

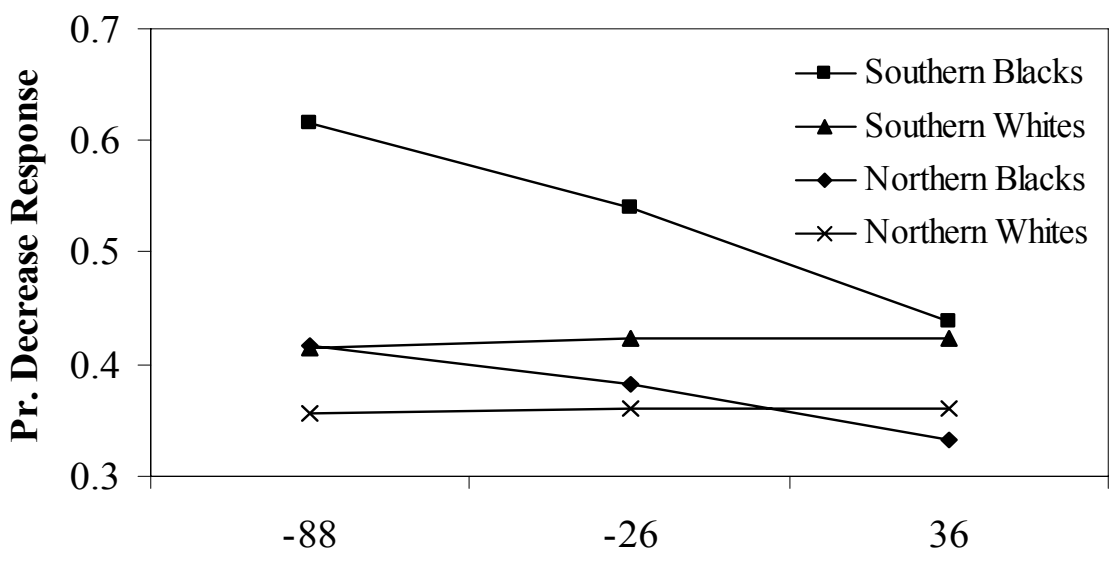

Black-Latino Ratio Change

Hispanic populations. The combination of that historical preoccupation with race and the novelty of Latinos in much of the South may explain this regional difference.

Of the three threat measures, only the change in the black-Latino ratio interacts significantly with race. The third results column in Table 1 shows the significant triple interaction of ratio change, region, and race (ratio 
change alone is insignificant). Panel B in Figure 1 illustrates the interaction effect for four groups: Southern blacks, Southern whites, Northern blacks, and Northern whites. Probabilities are plotted at the change mean $(-26 \%)$ and $\pm 1 S D(-88 \%$ and $+36 \%)$. The two flat lines indicate that whites are unresponsive to change in the ratio of blacks to Hispanics in the counties where they live. Whites are also unresponsive to change in the ratio of whites to Hispanics (not shown). Whites still tend to have very large population advantages over Latinos in even those counties where that ratio decreased the most, so their obliviousness may stem from a perception that they are still a large majority even when their own ratio to Latinos is cut.

Blacks in both regions, however, respond to changes in the blackLatino ratio. Southern blacks tend to favor decreasing immigration levels more than their Northern counterparts, but both groups become more likely to prefer a decrease as their own population advantages over Hispanics shrink. Thus, all other predictors being at their means, the respondents most in favor of decreasing immigration are African Americans living in Southern counties where the ratio of blacks to Latinos shrunk the most. As blacks are already minorities in most counties, their smaller populations may make changes in their comparative advantage over new Latino immigrants more evident than change in the white-Hispanic ratio is to majority whites, making them more responsive to this conceptualization of threat. As to the greater negativity of Southern blacks toward immigration, the novelty of Latinos in most of the region may drive this result.

The responsiveness of blacks to racial threat, then, is highly dependent upon how one operationalizes threat. Blacks are sensitive to their size advantage over Latinos, but just as oblivious as whites to other ways of measuring Latino population change. As Hispanics gain in size compared to their own group, that growing Latino population poses a greater threat to black interests. Latinos may become politically organized, gain growing attention or favor as the "new minority" in the community, and certainly present greater competition for resources such as jobs and affordable housing. Blacks, unlike whites, respond to their sense of how their group compares to Latinos in this competition.

Table 2 replicates the analysis in Table 1 on the 3-point border funding item. $^{7}$ The results and analysis are similar to those reported for immigration level attitudes. The first results column shows no significant interaction of county Latino percentage with region. This variable is also insignificant on its own and when interacted with race. Again, the traditional way of conceptualizing racial threat provides no leverage over immigration attitudes here. The second results column, however, shows a significant interaction of Hispanic population growth with the South dummy. Growth is insignificant alone and when interacted with race. Panel A in Figure 2 illustrates the 
Table 2. Support for Increasing Border Funding, 2000 NES

\begin{tabular}{|c|c|c|c|}
\hline & Latino $\%$ & Latino Growth & Ratio Change \\
\hline \multicolumn{4}{|l|}{ Political Attitudes } \\
\hline Authoritarianism & $-.003(.024)$ & $-.002(.024)$ & $-.002(.024)$ \\
\hline Out-Group Affect & $.013(.004)^{* * *}$ & $.013(.004)^{* * *}$ & $.013(.004)^{* * *}$ \\
\hline Out-Group Traits & $.013(.019)$ & $.013(.004)$ & $.012(.019)$ \\
\hline Ideology & $.104(.042)^{*}$ & $.103(.042)^{*}$ & $.099(.042)^{*}$ \\
\hline Partisanship & $.055(.035)$ & $.056(.035)$ & $.059(.035)+$ \\
\hline Economic Expectations & $-.009(.063)$ & $-.011(.063)$ & $-.017(.063)$ \\
\hline \multicolumn{4}{|l|}{ Demographics } \\
\hline Age & $.013(.004)^{* * *}$ & $.012(.004)^{* * *}$ & $.012(.004)^{* * *}$ \\
\hline Black & $.118(.179)$ & $.122(.179)$ & $.113(.184)$ \\
\hline Education & $-.181(.038)^{* * *}$ & $-.181(.038)^{* * *}$ & $-.178(.038)^{* * *}$ \\
\hline Female & $.075(.106)$ & $.070(.105)$ & $.078(.107)$ \\
\hline Income & $.010(.016)$ & $.011(.016)$ & $.010(.016)$ \\
\hline South & $-.257(.248)$ & $-.319(.239)$ & $-.297(.223)$ \\
\hline \multicolumn{4}{|c|}{ Threat Measures and Interactions } \\
\hline Latino $\%$ & $.443(.505)$ & & \\
\hline South X Latino \% & $-.673(.821)$ & & \\
\hline Latino Growth & & $-.001(.001)$ & \\
\hline South X Latino Growth & & $.006(.002)^{* * *}$ & \\
\hline Ratio Change & & & $.001(.001)$ \\
\hline Black X Ratio Change & & & $.301(.123)^{*}$ \\
\hline South X Ratio Change & & & $.006(.014)$ \\
\hline Black X South & & & $-.003(.002)$ \\
\hline Black X South X Ratio Change & & & $-.033(.016)^{*}$ \\
\hline$\tau_{1}$ & -1.827 & -1.926 & -1.890 \\
\hline$\tau_{2}$ & .266 & .167 & .206 \\
\hline LR & $79.26 * * *$ & $79.37 * * *$ & $86.46 * * *$ \\
\hline Pseudo- $\mathrm{R}^{2}$ & .057 & .070 & .078 \\
\hline $\mathrm{N}$ & 1551 & 1551 & 1551 \\
\hline
\end{tabular}

differing effect of growth percentage by region. Change in the Hispanic population itself has no effect on funding preferences for Northerners, but makes Southerners more likely to favor such spending.

The third column of estimates in Table 2 again shows a significant triple interaction of ratio change, race, and region. The ratio change variable is insignificant on its own, but the interaction term shows a conditional effect for this conceptualization of threat. Panel B in Figure 2 plots the 
Figure 2. Predicted Probabilities of Increased Border Funding Response

\section{A. Latino Growth Interaction}

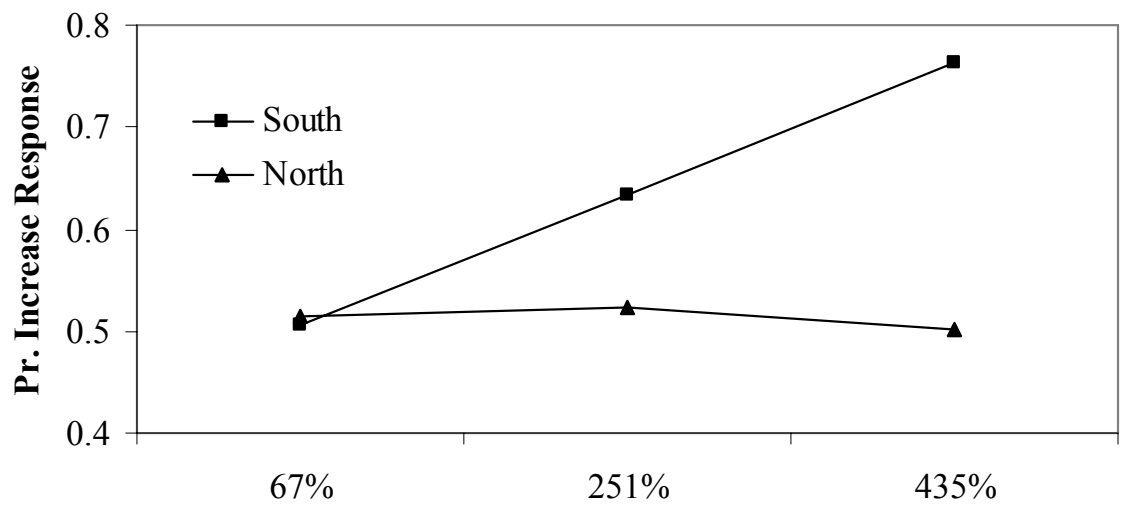

\% Latino Growth

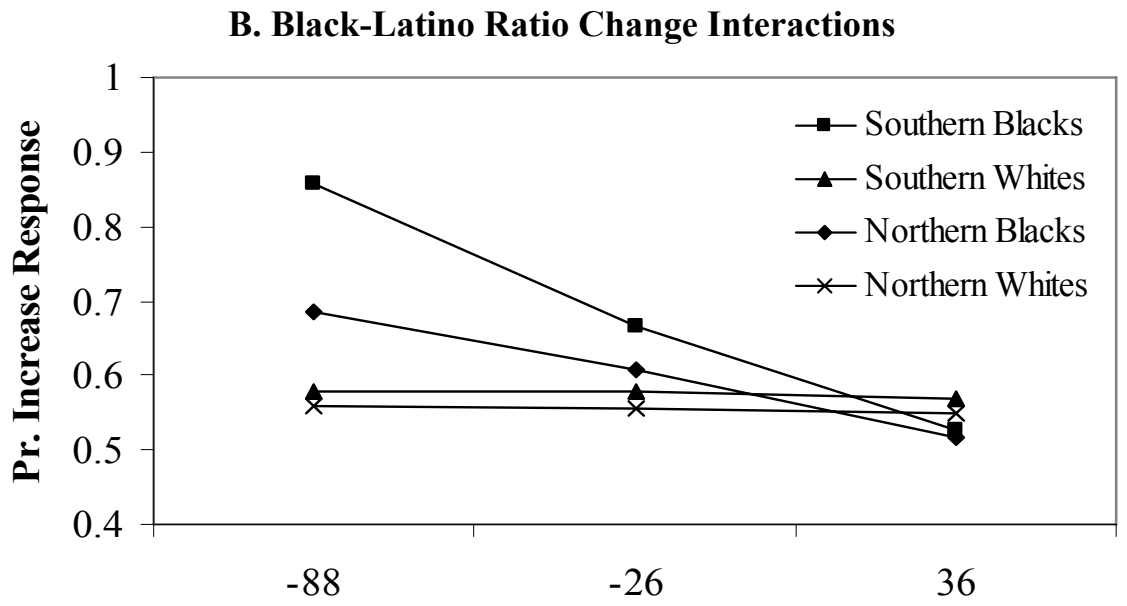

Black-Latino Ratio Change

predicted probability of an "increase" response for border funding. Whites are unresponsive to change in the ratio of African Americans to Latinos in the counties where they live, but this change does affect black respondents. Both northern and southern blacks become more likely to favor border funding as the size of the county black population shrinks in comparison to local Hispanics. Southern blacks again tend toward the more anti- 
immigration attitude than their northern counterparts, especially as their ratios to Latinos in the county drop the most. Whites are again unresponsive to how their own ratio to Latinos changes when that interaction is modeled.

\section{Discussion}

The diversification of America has upset the traditional racial balance of the South in ways that political science is only beginning to understand. For all the debate about continued Southern distinctiveness from the rest of America, the great amorphous "North," there is little question about its historical obsession with race and unique demographic profile that sets it apart from other regions. Yes, the South is joining the modern global economy and has developed a vibrant and well educated middle class that no longer relies upon the agricultural sector for its prosperity. The South is even evolving beyond its traditional black-white dichotomy to welcome immigrants from all corners of the world. In these respects, the Old South has virtually disappeared, but, as this article suggests, the history and culture of the region are arguably an influence on how Southerners are reacting to the profound changes the region is undergoing.

Beginning with Key (1949), scholars have demonstrated that racial threat is a significant influence on a variety of attitudes and behaviors, especially in the context of contentious race relations in the South. Little research, however, has pushed the study of threat beyond the black-white divide, especially into the context of the rapidly growing Latino population in the South. This article helps fill that empirical gap, and suggests that new ways of conceptualizing racial threat are needed to adequately capture the reality of threat induced by Hispanics. Throughout most of the South, Latinos are a new element in the racial profile of most communities. Indeed, the greatest growth in Latino populations in the South comes in localities with no established Hispanic population, unlike the North where Latino growth is more likely to occur in areas where Hispanics already reside. That dynamic, coupled with the salience of racial considerations to Southerners, creates an environment for racial threat to manifest itself in unique ways in the region.

Analyses here support the hypothesis that aggregate racial context as a proxy for threat is an important influence on immigration attitudes, but those effects are highly contingent upon how one conceives of the racial environment. Political scientists traditionally measure racial threat as the percentage of a minority group that lives in a specific geographic space, but that variable when translated into Latino population percentage in a county has no effect on immigration attitudes in this sample. Change in the Latino population itself, however, does shape how respondents feel about immigration, but 
only in the South. Given that Latinos are a small but new presence in most Southern communities, change may simply be a more appropriate way of conceptualizing racial context and how the average person perceives it. Thus, it may not be the perception that there are so many Hispanics around that matters, but the feeling that they are growing so fast. Furthermore, these data suggest that blacks alone are sensitive to how their group literally sizes up against Latinos in the local population, demonstrating that context may not be perceived in the same way by all subgroups. These results will hopefully encourage other researchers to think innovatively about how they operationalize racial context and, by extension, racial threat.

This research raises intriguing questions about the nature of any racial threat that Latinos induce. If their presence in a community spurs backlash by making the attitudes of individuals in those communities more negative toward policies like immigration that they associate with Latinos, then what is the specific threat Hispanics are perceived to pose? That question merits further research, especially in the South where Latinos are new to most communities and likely not fully integrated into local political and social life. The varying perceptions of threat among blacks and whites that this article demonstrates also suggest that different subgroups may perceive different sorts of threat from the growing presence of Latinos, another hypothesis worth further exploration.

As the data used here are from 2000, it is also an open question as to whether the threat dynamics demonstrated here are time-bound. After another decade of Latino expansion and, presumably, integration throughout the South, would the same threat measures produce similar results with more recent data? That question can easily be addressed once the appropriate data sets become available. Despite any limitations and unaddressed questions in this research, though, it should encourage us to think further about how we can best conceptualize racial threat in a rapidly diversifying society and how we can apply our knowledge of racial attitudes in the black-white context to accommodate growing "others" in the American and Southern racial profiles.

\section{NOTES}

${ }^{1}$ Some people prefer either the term "Latino/Latina" or "Hispanic," but I use them interchangeably. Mantero (2008) argues that both terms hold cultural and historical validity, and that Hispanic is the term most Americans use in everyday language. I am agnostic in this debate.

${ }^{2}$ While it seems more precise to match respondents with the lowest possible level of aggregation, there is a conceptual disadvantage to that. With Census tracts, for example, the demographics of many tracts in the South changed little in the 1990s even though the counties they were located in became more racially diverse. Placing respondents in their 
Census tracts, then, may be too small a level of aggregation as it may ignore changes in the larger community that affect the broader political environment around the respondent.

${ }^{3}$ As of this writing, the 2004 NES is the most recent for which geographic locators are available. However, the ACS only estimated demographics in 2004 for counties with at least 250,000 inhabitants. Replicating my analysis on 2004 would turn dozens of respondents living in smaller Southern counties with growing Latino populations into missing data. Thus, I felt the replication too systematically biased to pursue.

${ }^{4}$ Thanks to Thomas Carsey of the University of North Carolina at Chapel Hill for funding this purchase.

${ }^{5}$ Latino is an ethnicity in the Census, but many scholars treat it as a race (Garcia and Sanchez 2008).

${ }^{6} \mathrm{I}$ also tested the change in the Latino county population share from 1990 to 2000. If county $\mathrm{Z}$ was $5 \%$ Latino in 1990 but $7 \%$ in 2000 , then that change would be $2 \%$. That measure of change was insignificant for both immigration policies, as was its interaction with the black and South dummy variables.

${ }^{7}$ I also replicated this analysis on making English the official language. The pattern of results there is similar to those for immigration level, but is not shown given space limits. That analysis demonstrates, however, that threat from Latinos affects not just policies directly related to immigration, but also cultural issues such as an official language that are indirectly related to the immigration debate.

\section{REFERENCES}

Allport, Gordon W. 1954. The Nature of Prejudice. Cambridge: Addison-Wesley.

Amir, Yehuda. 1969. Contact Hypothesis in Ethnic Relations. Psychological Bulletin 71:319-342.

Black, Earle. 1976. Southern Governors and Civil Rights. Cambridge, MA: Harvard University Press.

Citrin, Jack, Donald Green, Christopher Muste, and Cara Wong. 1997. Public Opinion toward Immigration Reform: The Role of Economic Motivations. Journal of Politics 59:858-881.

Citrin, Jack, Beth Reingold, and Donald P. Green. 1990. American Identity and the Politics of Ethnic Change. Journal of Politics 52:1124-1154.

Ellison, Christopher G., and Daniel A. Powers. 1994. The Contact Hypothesis and Racial Attitudes Among Black Americans. Social Science Quarterly 75:385-400.

Fossett, Mark A., and K. Jill Kiecolt. 1989. The Relative Size of Minority Population and White Racial Attitudes. Social Science Quarterly 70:820-835.

Frendreis, John, and Raymond Tatalovich. 1997. Who Supports English-Only Language Laws? Evidence from the 1992 National Election Study. Social Science Quarterly 78:354-368.

Garcia, F. Chris, and Gabriel R. Sanchez. 2008. Hispanics and the U.S. Political System. Upper Saddle River, NJ: Pearson.

Giles, Michael W. 1977. Recent Black and Racial Hostility: An Old Assumption Revisited. Social Science Quarterly 58:412-417.

Giles, Michael W., and Arthur Evans. 1985. External Threat, Perceived Threat, and Group Identity. Social Science Quarterly 66:50-66.

Giles, Michael, and Kaenan Hertz. 1994. Racial Threat and Partisan Identification. American Political Science Review 88:317-326. 
Glaser, James M. 1994. Back to the Black Belt: Racial Environment and White Racial Attitudes in the South. Journal of Politics 56:21-41.

Goerman, Patricia L. 2006. The Promised Land? The Lives and Voices of Hispanic Immigrants in the New South. New York: Routledge.

Hetherington, Marc J., and Jonathan D. Weiler. 2009. Authoritarianism and Polarization in American Politics. Cambridge: Cambridge University Press.

Hood, M.V., and Irwin L. Morris. 1997. Amigo o Enemigo?: Context, Attitudes, and Anglo Public Opinion Toward Immigration. Social Science Quarterly 78:309-323.

Huckfeldt, Robert, and Carol Weitzel Kohfeld. 1989. Race and the Decline of Class in American Politics. Urbana: University of Illinois Press.

Jackman, Mary R., and Marie Crane. 1986. 'Some of My Best Friends are Black ...' Interracial Friendship and Whites' Racial Attitudes. Public Opinion Quarterly 50:459-486.

Key, V.O. 1949. Southern Politics in State and Nation. Knoxville: University of Tennessee Press.

Kinder, Donald R. 2003. Belief Systems after Converse. Pp. 13-47 in Electoral Democracy, ed. Michael MacKuen and George Rabinowitz. Ann Arbor: University of Michigan Press.

Kinder, Donald R., and Cindy D. Kam. 2009. Us Against Them: Ethnocentric Foundations of American Opinion. Chicago: University of Chicago Press.

Kinder, Donald R., and Tali Mendelberg. 1995. Cracks in American Apartheid: The Political Impact of Prejudice among Desegregated Whites. Journal of Politics 57: 402-424.

Mantero, Jose Maria. 2008. Latinos and the U.S. South. Westport, CT: Praeger.

Matthews, Donald R., and James W. Prothro. 1966. Negroes in the New Southern Politics. New York: Harcourt, Brace, and World.

McClain, Paula D. 1993. The Changing Dynamics of Urban Politics: Black and Hispanic Municipal Employment-Is There Competition? Journal of Politics 55:399-414.

McClain, Paula D. 2006. Presidential Address. 'Racial Intergroup Relations in a Set of Cities: A Twenty-Year Perspective.' Journal of Politics 68:757-770.

McClain, Paula D., Niambi M. Carter, Victoria M. DeFrancesco Soto, Monique L. Lyle, Jeffrey D. Grynaviski, Shayla C. Nunnally, Thomas J. Scotto, J. Alan Kendrick, Gerald F. Lackey, and Kendra Davenport Cotton. 2006. Racial Distancing in a Southern City: Latino Immigrants' Views of Black Americans. Journal of Politics 68:571-584.

McClain, Paula D., and Albert K. Karnig. 1990. Black and Hispanic Socioeconomic and Political Competition. American Political Science Review 84:535-545.

Meier, Kenneth J., Paula D. McClain, J.L. Polinard, and Robert D. Wrinkle. 2004. Divided or Together? Conflict and Cooperation between African Americans and Latinos. Political Research Quarterly 57:399-409.

Mohl, Raymond A. 2005. Globalization, Latinization, and the Neuvo New South. In Globalization and the American South, ed. James C. Cobb and William Stueck. Athens: University of Georgia Press.

Oliver, Eric J., and Tali Mendelberg. 2000. Reconsidering the Environmental Determinants of White Racial Attitudes. American Journal of Political Science 44:574-589.

Passel, Jeffrey S., and D'Vera Cohn. 2009. A Portrait of Unauthorized Immigrants in the United States. Pew Hispanic Center.

Pew Hispanic Center. 2005. The New Latino South: The Context and Consequences of Rapid Population Growth.

Pettigrew, Thomas F. 1971. Racially Separate or Together? New York: McGraw-Hill. 
Powers, Daniel, and Christopher Ellison. 1995. Interracial Contact and Black Racial Attitudes. Social Forces 74:205-227.

Reimers, David M. 2005. Asian Immigrants in the South. In James C. Cobb and William Stueck, eds. Globalization and the American South. Athens: University of Georgia Press.

Rieder, J. 1985. Canarise: The Jews and Italians of Brooklyn Against Liberalism. Cambridge: Harvard University Press.

Scheve, Kenneth F., and Matthew J. Slaughter. 2001. Globalization and the Perceptions of American Workers. Washington, DC: Institute for International Economics.

Sigelman, Lee, and Susan Welch. 1993. The Contact Hypothesis Revisited: Black-White Interaction and Positive Racial Attitudes. Social Forces 71:781-795.

Stephan, Walter G., and Cookie White Stephan. 1985. Intergroup Anxiety. Journal of Social Issues 41:157-175.

Stein, Robert M., Stephanie Shirley Post, and Allison L. Rinden. 2000. Reconciling Context and Contact Effects on Racial Attitudes. Political Research Quarterly 53:285-303.

Taylor, Marylee C. 1998. How White Attitudes Vary with the Racial Composition of Local Populations: Numbers Count. American Sociological Review 63:512-535.

Welch, Susan, Lee Sigelman, Timothy Bledsoe, and Michael Combs. 2001. Race and Place: Race Relations in an American City. New York: Cambridge University Press.

Wright, Gerald C., Jr. 1977. Contextual Models of Electoral Behavior: The Southern Wallace Vote. American Political Science Review 71:497-508. 